\title{
Persistent postoperative granulation tissue following vaginal prolapse repair
}

\author{
Amandeep Mahal, MD, ${ }^{1}$ Tao Zhang, PhD, Miriam B. Zimmerman, PhD, ${ }^{2}$ Ali Luck, MD,3 \\ Catherine S. Bradley, MD, MSCE ${ }^{1}$
}

Keywords: granulation tissue, postoperative complications, vaginal prolapse

\section{Objective}

To report rates and risk factors for persistent postoperative granulation tissue (GT) in women undergoing reconstructive vaginal prolapse surgery.

\section{Materials and Methods}

This retrospective cohort study used procedure codes to identify all patients who underwent vaginal-approach reconstructive prolapse surgery over a 3-year period. Demographic, medical history, medications, operative details and follow-up data were obtained via chart review. Surgical procedures, suture and implant types were abstracted from operative notes. Rates of pre-specified outcomes, including persistent GT (GT on exam > 2 months after surgery) and reoperation for GT, were calculated by procedure. Associations were studied between potential risk factors and GT outcomes.

\section{Results}

164 patients underwent vaginal reconstructive prolapse surgery by two attending surgeons. One was excluded (no postoperative exam), leaving 163 patients with median (range) 5 (1-39) months follow-up. Mean \pm SD age was $60 \pm 13$ years. $35 \%$ and $23 \%$ had prior hysterectomy and prolapse surgery, respectively. $12 \%$ smoked. Procedures included hysterectomy $(36 \%)$, apical

${ }^{1}$ Department of Obstetrics and Gynecology, Carver College of Medicine, University of lowa Hospitals and Clinics, lowa City, IA, 52242

${ }^{2}$ College of Public Health, University of lowa, lowa City, IA 52242

${ }^{3}$ Henry Ford Health Systems, West Bloomfield, MI, United States

Please cite this abstract as: Mahal A, Zhang T, Zimmerman MB, Luck A, Bradley CS. Persistent postoperative granulation tissue following vaginal prolapse repair. Proc Obstet Gynecol. 2013;3(3):Article 12 [ 2 p.]. Available from: http://ir.uiowa.edu/pog/. Free full text article.

Corresponding author: Amandeep Mahal, Department of Obstetrics and Gynecology, University of lowa, 200 Hawkins Drive, lowa City, IA 42242, amandeep-mahal@uiowa.edu

This is an Open Access article distributed under the terms of the Creative Commons Attribution 3.0 Unported License (http://creativecommons.org/licenses/by/3.0), which permits unrestricted use, distribution, and reproduction in any medium, provided the original work is properly cited. 
suspension (53\%), anterior repair $(37 \%)$, anterior repair with graft $(40 \%)$, posterior repair $(60 \%)$, and posterior repair with graft $(14 \%)$. 84 of 85 grafts placed were biologic (all cross-linked porcine dermis). Permanent suture was used in $76(89 \%)$ graft placements, including braided polyester (73) and polypropylene (3), and in $81(93 \%)$ apical suspensions, including braided polyester (41), polytetrafluoroethylene expanded polypropylene (5). Persistent GT occurred in $31(19 \%)$ patients, and 7 (4\%) had re-operation for GT at median (range) 10 (5-28) months after initial surgery. The highest rates of persistent GT and re-operation occurred in patients who had iliococcygeal suspension (all with braided polyester ) (82 and $45 \%$, respectively) and anterior graft placement $(24$ and $6 \%$, respectively). (See Table.) All patients who had re-operation (7 patients, 8 surgeries) had permanent braided polyester sutures removed. In addition to use of braided polyester, multivariate analysis suggested use of anterior graft and apical suspension significantly increased the risk of persistent GT. Patient-related factors were not associated with persistent GT.

\section{Conclusion}

Postoperative persistent granulation tissue was not uncommon (19\%) in this cohort of native tissue and biologic graftaugmented vaginal prolapse surgery patients. Anterior biologic graft placement, apical suspension, and in particular, use of braided polyester suture are procedure-related risk factors for persistent granulation tissue.
Presented at "Controversies in the Care of Women with PREECLAMPSIA A NATIONAL DEBATE," the University of lowa Obstetrics and Gynecology Postgraduate conference, 18 October 2013, hotelVetro \& Conference Center, lowa City, lowa 52240. 